\title{
Rod-shaped nuclear viruses of crustaceans: hemocyte-infecting species
}

\author{
Phyllis T. Johnson \\ National Marine Fisheries Service, Northeast Fisheries Center, Oxford, Maryland 21654, USA
}

\begin{abstract}
Rod-shaped, enveloped, nonoccluded nuclear viruses have been found in hemocytes of the brachyuran portunid crabs Callinectes sapidus, Carcinus maenas, and Carcinus mediterraneus. The morphology and probable mode of development of these related viruses are described and illustrated, and possible relationships of the viruses to members of the Baculoviridae and other rod-shaped viruses are discussed. The hemocyte-infecting viruses, although they share certain characteristics with various baculoviruses, differ in that the nucleocapsid is not a true cylinder, which is also the case with the Polydnaviridae and a number of the rod-shaped nuclear viruses whose relationships are still unstudied.
\end{abstract}

\section{INTRODUCTION}

The 9 rod-shaped nuclear viruses known from crustaceans can be separated into 2 groups according to their morphologies and the tissues they infect. Members of the most numerous and diverse group infect nuclei of the midgut epithelium, mainly that of the hepatopancreas. These viruses, which are morphologically very similar to certain accepted members of the Baculoviridae and involve both occluded and nonoccluded species, are discussed by Johnson \& Lightner (1988: companion article). The second, smaller group is the subject of this paper The 3 known species are related to one another and are morphologically and developmentally less like typical baculoviruses. They are nonoccluded and infect mesodermally derived cells, mainly hemocytes and hemopoietic cells. Hosts are brachyuran crabs of the family Portunidae.

\section{MATERIALS AND METHODS}

For light microscopy, tissues were fixed in Helly's solution (Johnson 1980) and stained by the Feulgen technique, using picric acid and methyl-blue counterstains (Farley 1969). Primary fixation for tissues used in electron microscopy was in cold $4 \%$ glutaraldehyde in $0.1 \mathrm{M}, \mathrm{pH} 7.4$, Sorenson's phosphate buffer. Storage up to several weeks was in the glutaraldehyde solution at $4{ }^{\circ} \mathrm{C}$. Tissues were postfixed at room temperature in $1 \%$ osmium tetroxide in the phosphate buffer, dehy- drated in ethanol and propylene oxide and embedded in Spurr's low viscosity embedding medium (Spurr 1969) or in an Epon/Araldite mixture (1:1). Thin sections were stained with uranyl acetate and lead citrate and viewed with a Zeiss EM 9S 2 electron microscope.

The terms used here to describe viral structure are defined as follows: capsid = the proteinaceous cylinder that encloses the viral nucleoprotein $=$ viral DNA and its accompanying protein; core = the viral nucleoprotein contained within the capsid; nucleocapsid = the capsid plus the core; envelope = the membranous structure that encloses a capsid or nucleocapsid; virion $=\mathrm{a}$ mature and presumably infectious viral particle consisting of an enveloped nucleocapsid $;$ capsid originator $=\mathrm{a}$ structure that appears to give rise to the capsid.

\section{OBSERVATIONS}

Bazin et al. (1974) found a nonoccluded virus in hemocytes and connective-tissue cells in regenerating limb buds of European Carcinus maenas. An apparently identical virus infects the same tissues of Carcinus mediterraneus (J. Mari \& J.-R. Bonami pers. comm.). The rod-shaped virus that infects hemocytes and hemopoietic tissue of Callinectes sapidus, the blue crab, is very like the one from European Carcinus and may prove to be the same. The third virus known in this group infected hemocytes and hemopoietic tissue of a single individual of $C$. maenas taken from the Atlantic coast of North America. Although morphologically 
similar to the viruses from $C$. sapidus and European Carcinus species, size differences and some other characters indicate that it is different.

Ability of these viruses to cause disease is unknown. Other viruses were always present in blue crabs infected with the rod-shaped virus, and the American Carcinus may have been abnormal in other ways.

The viruses from American Carcinus maenas and Callinectes sapidus are described and compared here.

\section{Hemocytic virus of American Carcinus maenas (RV-CM)}

RV-CM (rod-shaped virus of Carcinus maenas) is described here for the first time. It infected hemocytes and cells in the hemopoietic tissue, and was found in 1 of 29 C. maenas collected on the same date at Woods Hole, Massachusetts, USA. It was the only infected individual found in a total of $74 \mathrm{C}$. maenas collected at various times from Woods Hole during 1982-83. The infected crab had been in the laboratory for $12 \mathrm{~d}$ and was behaviorally normal on the day of dissection. Its hemolymph was milky and contained numerous small granules in addition to the usual complement of hemocytes. Cellular aggregation in the withdrawn hemolymph was much less than normal, and cells that did aggregate were in groups of only 2 or 3 . The crab was also heavily infected with a rhabdolike virus similar to EHV of the blue crab (Johnson 1983, 1984), and it was not possible to assume that abnormalities in cellular clotting and in the hemolymph were due solely or in part to RV-CM.

Tissue sections examined with the light-microscope had many RV-CM-infected cells in the hemopoietic tissue and others free in the hemolymph. A few infected nuclei were up to 2 times normal size, but many were enlarged little or not at all. RV-CM-infected nuclei stained by the Feulgen method appeared like ones infected with the similar virus of the blue crab (Fig. 13).

\section{Electron microscopy}

Infected nuclei had marginated chromatin and sometimes contained one or more nucleoli (Fig. 1). A finely fibrillar or granular substance, considered to represent the virogenic stroma, filled the nucleus. In nuclei with light and presumably early infections there were groups of vesicles that usually contained some particulate material. Viral particles and pieces of membrane were associated with the vesicles and also scattered through the nucleus (Fig. 2). Virions and vesicles occurred more evenly through the nucleus in heavy infections.
The proposed developmental scheme described here was based on examination of numerous sections of infected nuclei, many of which contained all the putative stages of development. The first visible evidence of possible capsid formation was a spherical object in association with a piece of membrane (Figs. 3 and 6). This object, here conditionally designated the 'capsid originator', was 53 to $64 \mathrm{~nm}$ in diameter, sometimes had a less dense center, and occasionally exhibited evenly spaced rays or granules on its surface. It appeared to become the specialized apex of the capsid (see below), with the capsid proper growing from it. Developing capsids had the longitudinal axis at a $90^{\circ}$ angle to the associated membrane (Fig. 4). Apparently the curved sheet of membrane present during early development later extended along the length of the growing capsid, finally enclosing it in a tube with one open end (Fig. 5). Presumably complete capsids had squared ends and were of moderate density. The specialized apex, which was at the open end of the envelope, was considerably denser than the remainder of the capsid and sometimes apically serrate or frayed (Fig. 5). Often more than one viral particle was associated with a single piece of membrane and these particles were usually at different stages of development (Figs. 4 and 6). The rare occurrence of 2 viral particles apparently within a single envelope probably resulted from such associations (Fig. 7). Empty capsids surrounded by an open-ended tubular envelope and assumed to be complete were usually 65 to $70 \mathrm{~nm} \times$ 210 to $280 \mathrm{~nm}$. However, there were capsids as short as $95 \mathrm{~nm}$ and as long as $760 \mathrm{~nm}$ that appeared to be complete because they were either entirely enveloped or the envelope formed a tube that extended the entire length of the capsid (Fig. 8). Only one capsid and one nucleocapsid that appeared to completely lack envelopes were detected in the available material. It is proposed that the nucleoprotein of the core was inserted centrally along the length of the capsid, first forming a helical filament that extended the full length of the capsid (Fig. 9A), and that the filament lost its helical appearance as it broadened during further filling of the capsid with nucleoprotein (Fig, 9B, C). With a diameter of 95 to $110 \mathrm{~nm}$, completed nucleocapsids were considerably broader than empty capsids (Fig. 6). They were $190 \mathrm{~nm}$ to $540 \mathrm{~nm}$ long, although most were between 235 and $280 \mathrm{~nm}$ long (Figs. 5 and 9). A newly completed nucleocapsid was straight, with the envelope fitting loosely along its length. The apex at the closed end of the envelope was rounded and the squared specialized apex at the open end was like that of the empty capsid (Fig. 6). The capsid was 11 to $12 \mathrm{~nm}$ thick along the length of the core, and sometimes separated slightly from it. The capsid was less electron dense than the core, and easily distinguished from it. 

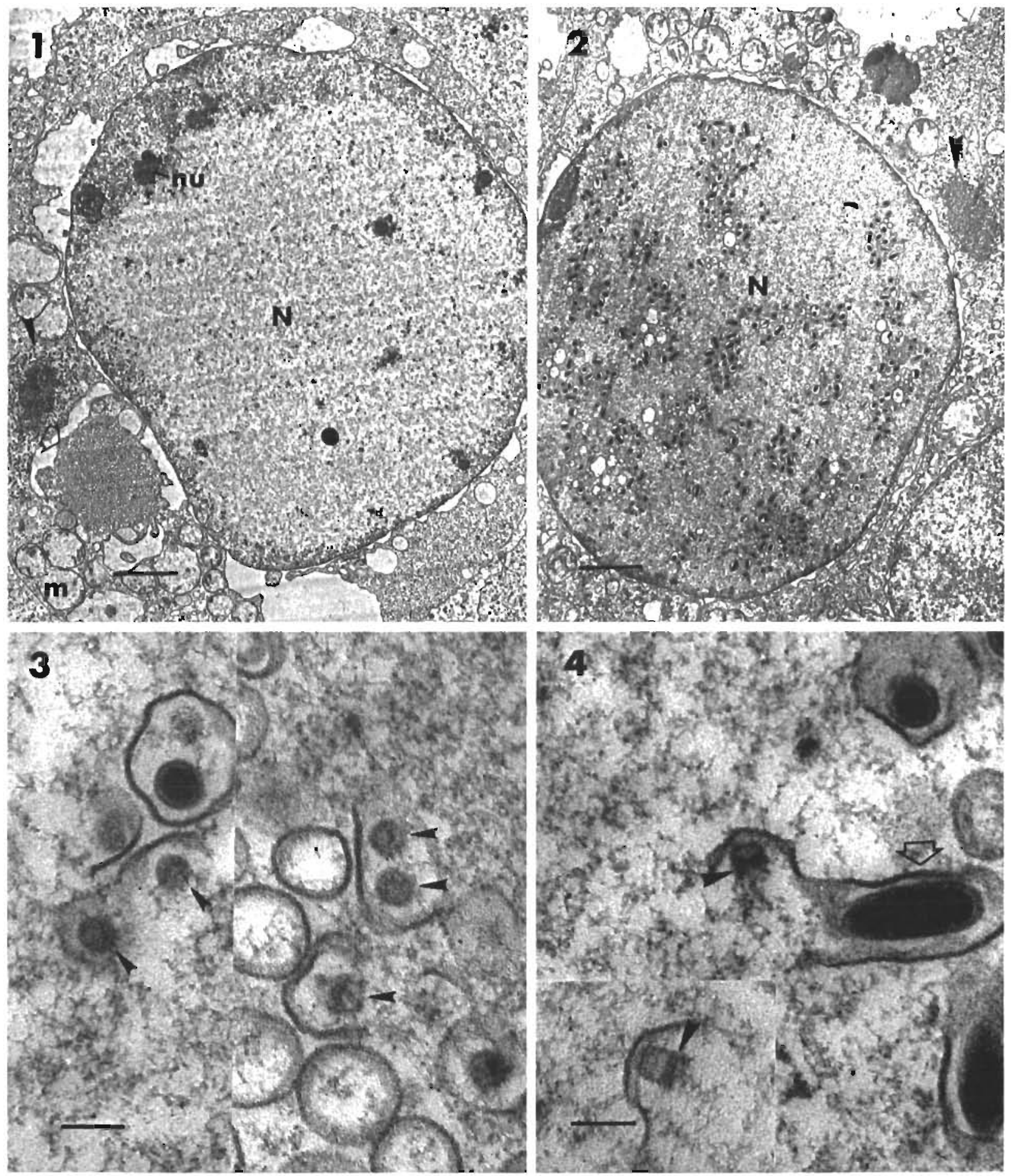

Figs. 1 to 4. RV-CM. Fig. 1. Early infection In the cytoplasm are a reticulum formed of microtubules (open arrow) and the virogenic stroma of a rhabdolike virus (arrow). Note the abnormal mitochondria Bar $=137 \mathrm{~nm} \mathrm{~m}$ mitochondrion; N. nucleus; nu nucleolus. Fig. 2. More advanced infection Note groups of vesıcles and virions There 15 a virogenic stroma of a rhabdolike virus in the cytoplasm (arrow). Bar $=137 \mathrm{~nm}$. N nucleus. Fig. 3. Montage of capsid originators (arrows) Bar $=93 \mathrm{~nm}$. Fig. 4. Montage showing very early development of the capsid The dense portion farthest trom the associated membrane is assumed to be the capsid originator (arrows). A completed nucleocapsid is assoclated with the same membrane, to the nght (open arrow) Bar = 

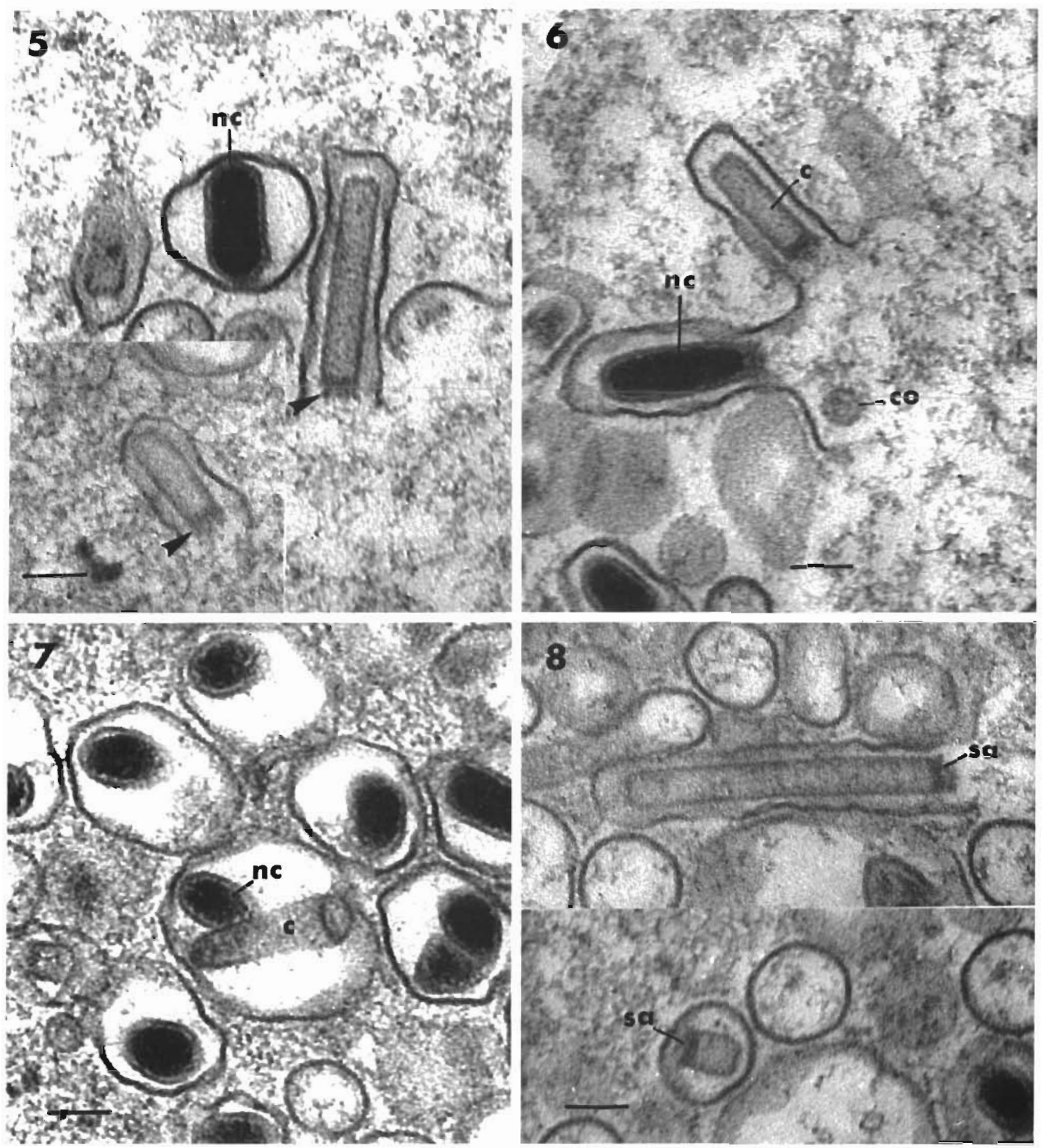

Figs 5 to 8 RV-CM Flg 5 Developing capsids. Note the frayed appearance of the specialized end (arrows). An abnormally short nucleocapsid is also present. Bar $=93 \mathrm{~nm}$. nc: nucleocapsid. Fig. 6 . Developing particles of different ages associated with the same piece of membrane. Bar $=93 \mathrm{~nm}$. c: capsid; co: capsid originator; nc: nucleocapsid. Fig. 7. Empty capsid and nucleocapsid apparently occupying the same envelope. Bar $=93 \mathrm{~nm}$. c: capsid; nc: nucleocapsid. Fig. 8 . Montage of abnormally long and short capsids $\mathrm{Bar}=93 \mathrm{~nm}$. sa: specialized apex

The specialızed apex of fully enveloped nucleocapsids was not always discernible.

In sagittal section, the edge of the core sometimes appeared to be tormed of a row of hemispheres or cubes (Fig 10) In grazing sections, there was a superficial grid with openings about $8 \mathrm{~nm}$ in diameter on the core surface (Fig. 10).

The envelope was 7 to $9 \mathrm{~nm}$ thick and it became 


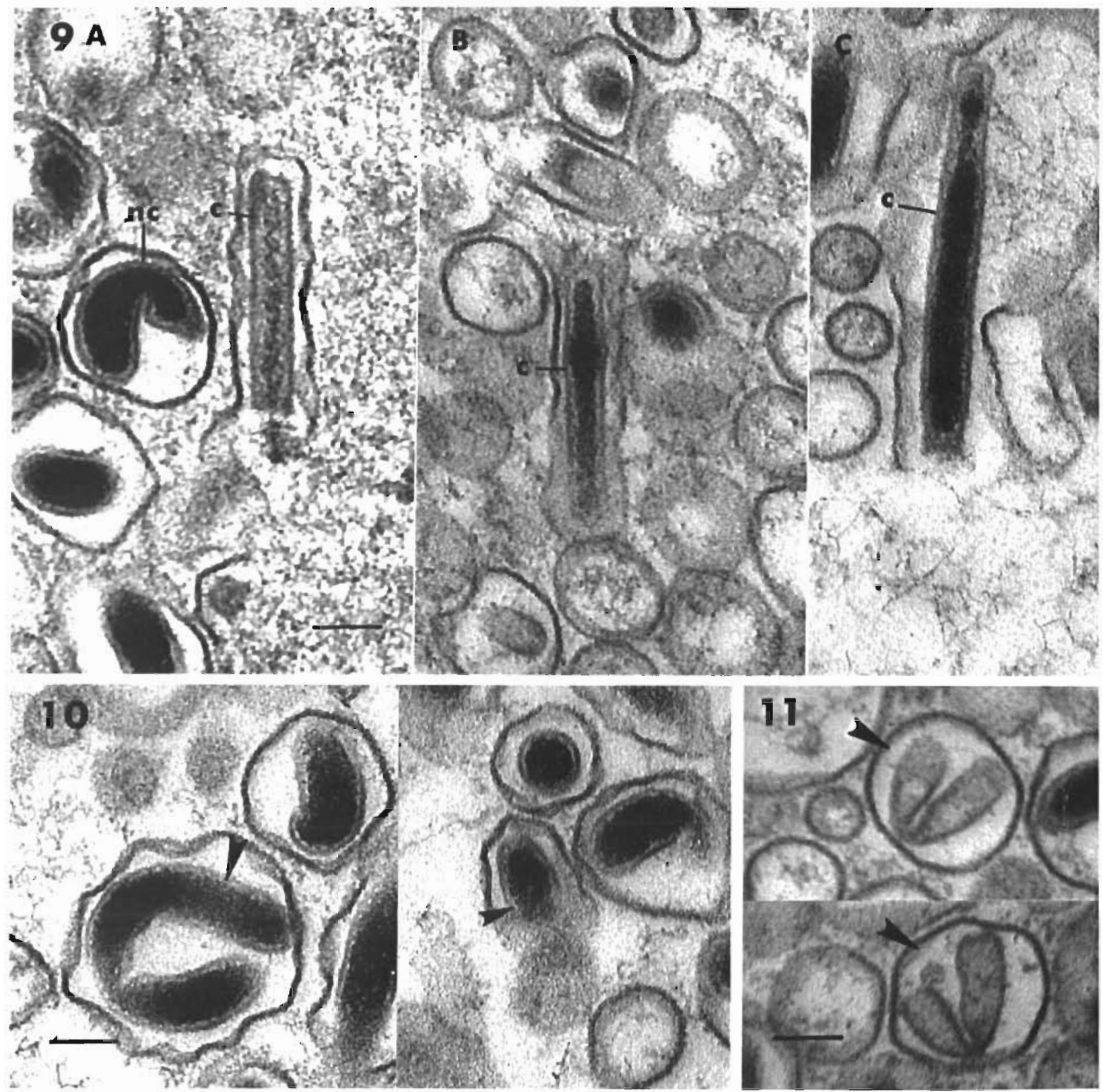

Figs. 9 to 11. RV-CM. Fig. 9. Filling of capsıd with nucleoprotenn (A) Helical central filament is present (B. C) Two later stages.

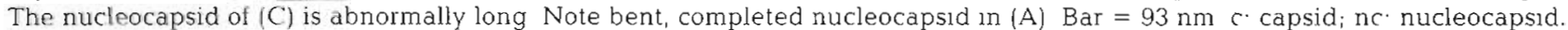
Fig. 10. Montage. There is an abnormally long, bent nucleocapsid with indication of a gridlike structure on the core surface (arrow), and a sacitally sectioned nucleocapsid with squares lining the margin of the core (arrow). Bar $=93 \mathrm{~nm}$. Fig 11 . Montage of V-shaped capsids (arrows) Bar $=93 \mathrm{~nm}$

spherical or nearly so after it was closed. Thus apparently forced the nucleocapsid into a curved shape so that it could fit within the now shortened envelope. Curvature of the viral particles could be so pronounced that nucleocapsids and the occasional completely enveloped empty capsids were bent into $U$ or $V$ shapes (Figs. 9 to 11 ).

The cytoplasm of infected cells contanned free ribosomes, expanded and vesicular endoplasmic reticulum, and mitochondna that were swollen and losing their cristae, even though the outer mitochondrial membrane remained enture. Simular endoplasmic retrculum and mitochondria were present in uninfected cells. Occasionally there was a large group of mlcrotubules in an interconnected reticulum that was limited by membranes and vesicles (Figs. 1 and 12) 
Commonly, RV-CM-infected cells also harbored a cytoplasmic rhabdolike virus related to EHV of the blue crab. Its stroma is shown in Figs. 1 and 2.

\section{Hemocytic virus of Callinectes sapidus (Baculo-B)"}

Baculo- $B$ of the blue crab infects undifferentiated hemocytes and cells still within the hemopoietic tissue (Johnson 1983, 1984). Infected crabs originated from tributaries of Chesapeake Bay, Maryland, and from Chincoteague Bay, Virginia, USA. The ability of Baculo-B to cause disease has not been established. It occurred in apparently normal crabs, and sick crabs inferted with Baculo-B also harbored other viruses or protistans known to be pathogenic. Seven of the infected crabs had been used in attempts to transmit other viruses, and had been injected with hemolymph from crabs that later proved to have been infected with Baculo- $B$ as well as with the viruses being studied. Presumably, Baculo-B had been transmitted to at least some of these crabs by the injection of infected hemolymph. Natural infections occurred in crabs maintained 0 to $50 \mathrm{~d}$ in the laboratory. Only 19 Baculo-B infections ( 7 in the virus-transmission series) were recognized in 1500 blue crabs examined histologically, suggesting that this virus either is not common or does not usually cause cellular changes distinguishable with the light microscope. How Baculo-B enters the hemocoel and how it infects cells are unknown.

Overtly infected cells were easily distinguished with the light microscope. Their nuclei were hypertrophied, up to 1.6 times normal size, evenly and often strongly Feulgen positive, and thinly rimmed with intensely Feulgen-positive material. Multiple, small, intensely Feulgen-positive inclusions were present in a few infected nuclei. The basophilic cytoplasm was often reduced to a thin rim around the nucleus (Fig. 13).

\section{Electron microscopy}

The 7 crabs investigated by electron microscopy were infected with 1 to 3 cytoplasmic viruses in addition to Baculo-B, and multiple infection of the same cell sometimes occurred. Multiple viral infection did not modify appearance of Baculo-B particles or Baculo-Binfected nuclei.

\footnotetext{
- 'Baculo-B' is firmly established in the literature as the name for the Callinectes virus. The name may prove to be inappropriate. It is to be hoped that eventually a logical and consistent naming system will be devised for the viruses infecting marine invertebrates. Until then, only more confusion would result from piecemeal and inconsistent renaming of these viruses
}

The first signs of infection were much like those of RV-CM. In addition, there was a marginal band of variable width next to the nuclear membrane that occupied all of the nucleus not filled by the stroma. It was comprised of particles similar to ribosomal precursor particles of the nucleolus (Alberts et al. 1983) (Figs. 14 and 15). An organized nucleolus was occasionally present. Short profiles of membrane, irregularly curved or circular, appeared first in the stroma, followed by developing and mature viral particles and variously sized and shaped vesicles (Fig. 14). Virions did not extend into the marginal band. They either occurred randomly through the stroma or formed ordered arrays (Fig. 15).

In some infected nuclei either the inner or the outer nuclear membrane plus the nuclear cisterna were missing in areas, so that a single membrane separated cytoplasm from nucleus. Some nuclear pores in such nuclei were broader than normal. These configurations suggested that merging of cytoplasm and nucleus was taking place. In one cell the infected nucleus had lost its integrity, Baculo-B virions were in the cytoplasm together with 2 cytoplasmic viruses, and 'nuclear pores' traversed cisternae between areas presumed to be essentially cytoplasmic because they contained cytoplasmic viruses (Fig. 16).

As with RV-CM, capsids developed in association with membrane and capsid formation apparently began with a capsid originator, 53 to $64 \mathrm{~nm}$ in diameter and with a less dense center that occasionally contained an opaque dot (Fig. 17). The capsid originators were sometimes surrounded by short rays or spikes, and sometimes were completely circled by membrane, suggesting they were either in cup-shaped membranes or were completely enveloped. Capsid originators not completely circled by membrane were also present (Fig. 14). Empty capsids were rare, and their stepwise development was not so clearly shown as in RV-CM. However, short and incompletely enveloped capsids were occasionally observed. Development of the capsid appeared to follow that of RV-CM, with mature capsids being enclosed in an open-ended tubular envelope that covered the entire length either loosely or closely (Fig. 18). Presumably completed capsids had squared or bluntly rounded ends and were normally 53 to $60 \mathrm{~nm} \times 220$ to $280 \mathrm{~nm}$, but one capsid $350 \mathrm{~nm}$ long and several 100 to $120 \mathrm{~nm}$ long were noted. Rarely, naked capsids less than $100 \mathrm{~nm}$ long were palisaded at the edge of the stroma (Fig 19). Otherwise, naked capsids were not detected, but one naked nucleocapsid was found (Fig. 20).

As with RV-CM, the core apparently was first inserted centrally, along the longitudinal axis of the capsid (Fig. 20). Nucleocapsids were slightly fusiform with a bluntly rounded apex at the closed end of the 

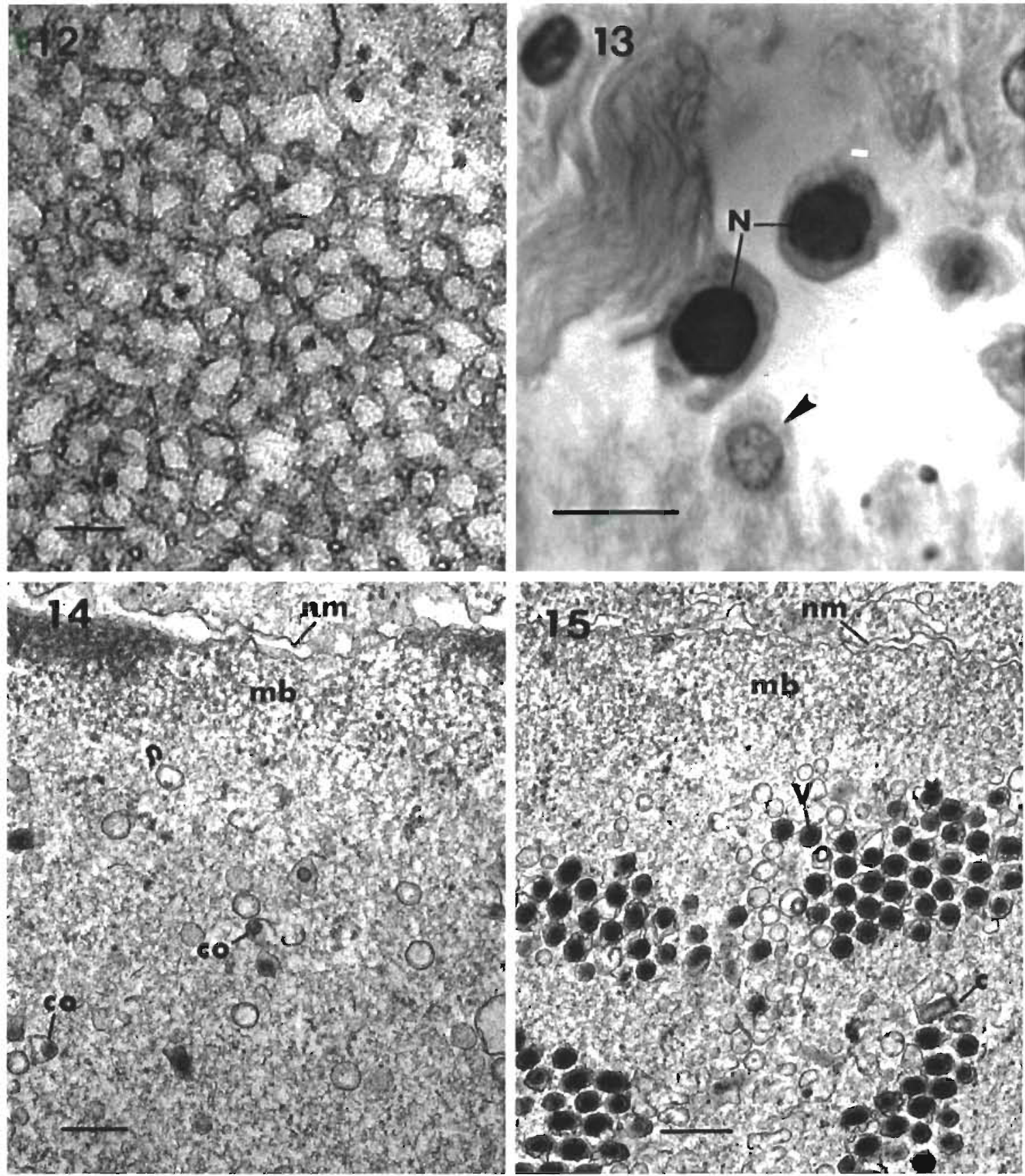

Fig. 12. RV-CM Reticular mass of cytoplasmic microtuoules. Bar $=93 \mathrm{~nm}$

Figs. 13 to 15. Baculo B. Fig. 13. Light micrograph of unfected hemocytes A normal hemocyte 1 also present (arrow) Bar $=10$ um $\mathrm{N}$ : infected nucleus. Fig. 14. Early infection $\mathrm{Bar}=271 \mathrm{~nm}$ co capsid originator, mb marginal band; nm. nuclear membrane Fig 15. Developing and completed particles, some in ordered arrays Bar $=271 \mathrm{~nm}$ c empty capsid; mb: marginal band, nm nuclear membrane, $V$ virion

envelope and a squared apex at the open end (Figs. 21, 22 and 23). The capsid was thicker apıcally than along the length of the core, where it was 11 to $16 \mathrm{~nm}$ thick. The squared end of the nucleocapsid presumably was homologous with the specialized apex of RV-CM par- ticles. The nucleocapsid was broader than the empty capsid, being 75 to $85 \mathrm{~nm}$ at its broadest point, and was 220 to $260 \mathrm{~nm}$ long. Closely enveloped virions were 85 to $100 \mathrm{~nm} \times 370$ to $390 \mathrm{~nm}$, and the envelope, which was thinner than that of RV-CM, was 5 to $6 \mathrm{~nm}$ thick. 

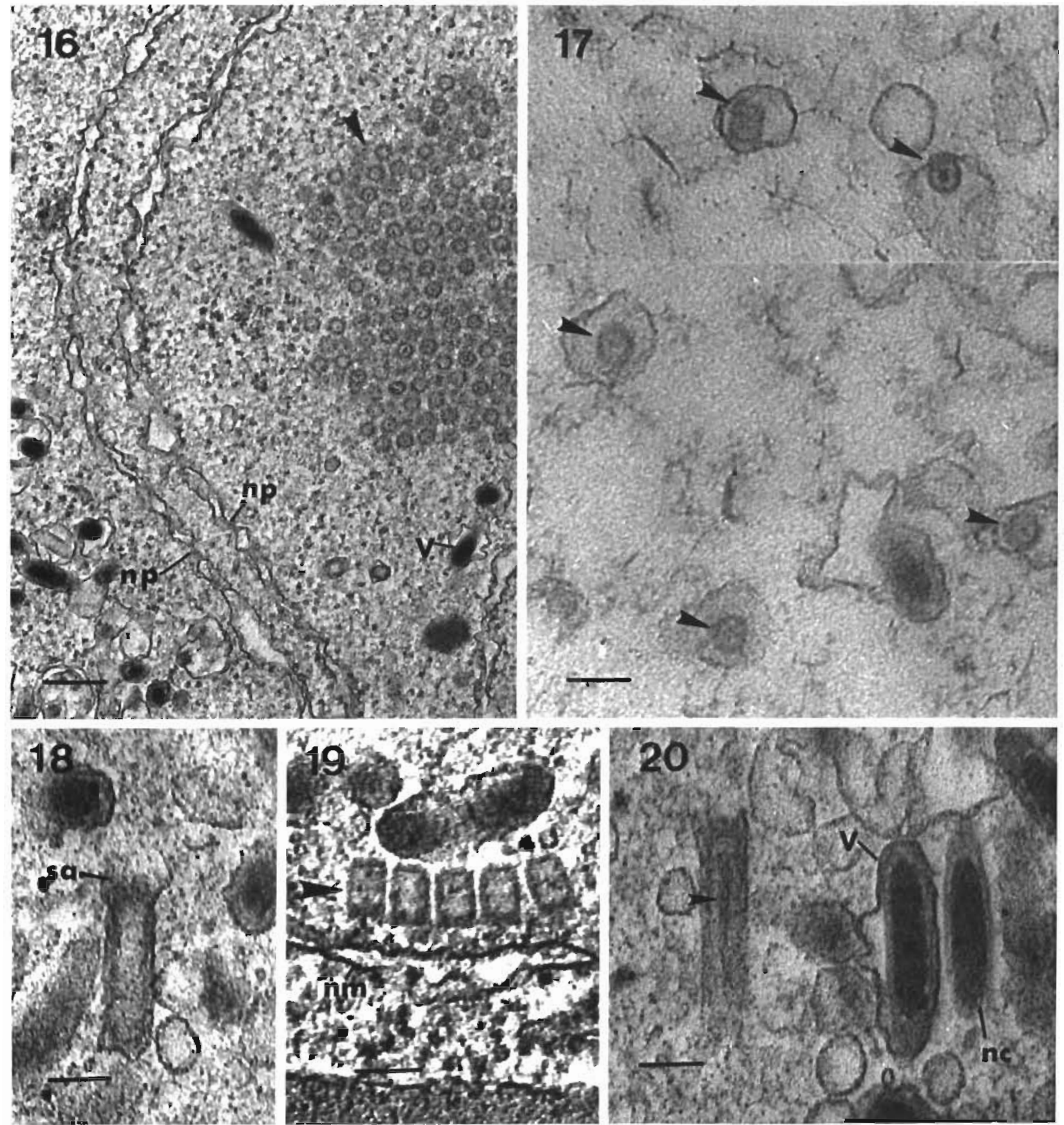

Figs 16 to 20 Baculo-B. Fig. 16. Cytoplasmic and nuclear domains are intermıngled Baculo-B virions occur with a cytoplasmic vrus, RLV (arrow) There are 'nuclear pores' traversing cisternae in the cytoplasm. Bar = $271 \mathrm{~nm}$. np: 'nuclear pore'; V: virion of Baculo-B Fig. 17. Montage of putatıve capsid onginators (arrows). Bar $=93 \mathrm{~nm}$. Fig. 18. Baculo-B. Completed empty capsid in an open-ended envelope. Bar $=93 \mathrm{~nm}$. sa: specialized apex. Fig. 19. Palisaded, naked, abnormally short capsids (arrowi. Bar = $93 \mathrm{~nm} \mathrm{~nm}$ : nuclear membrane. Fig. 20. Capsid with a central nucleoprotein filament (arrow). To the right are a virion and it naked nucleocapsid. Bar $=93 \mathrm{~nm}$. nc: naked nucleocapsid; $V \cdot$ virion

Even when tairly closely fitted, envelopes were wrinkled (Fig 23) or complexly folded (Fig 24)

A few infected nucles had amorphous, opaque inclusions in the stromal area, possibly accumulations of viral nucleoprotein and the same as the rare, brightly Feulgen-positive inclusions visible with the light microscope. Density of the fibrillar material of the virogenuc stroma varied; nuclei with extremely dense 

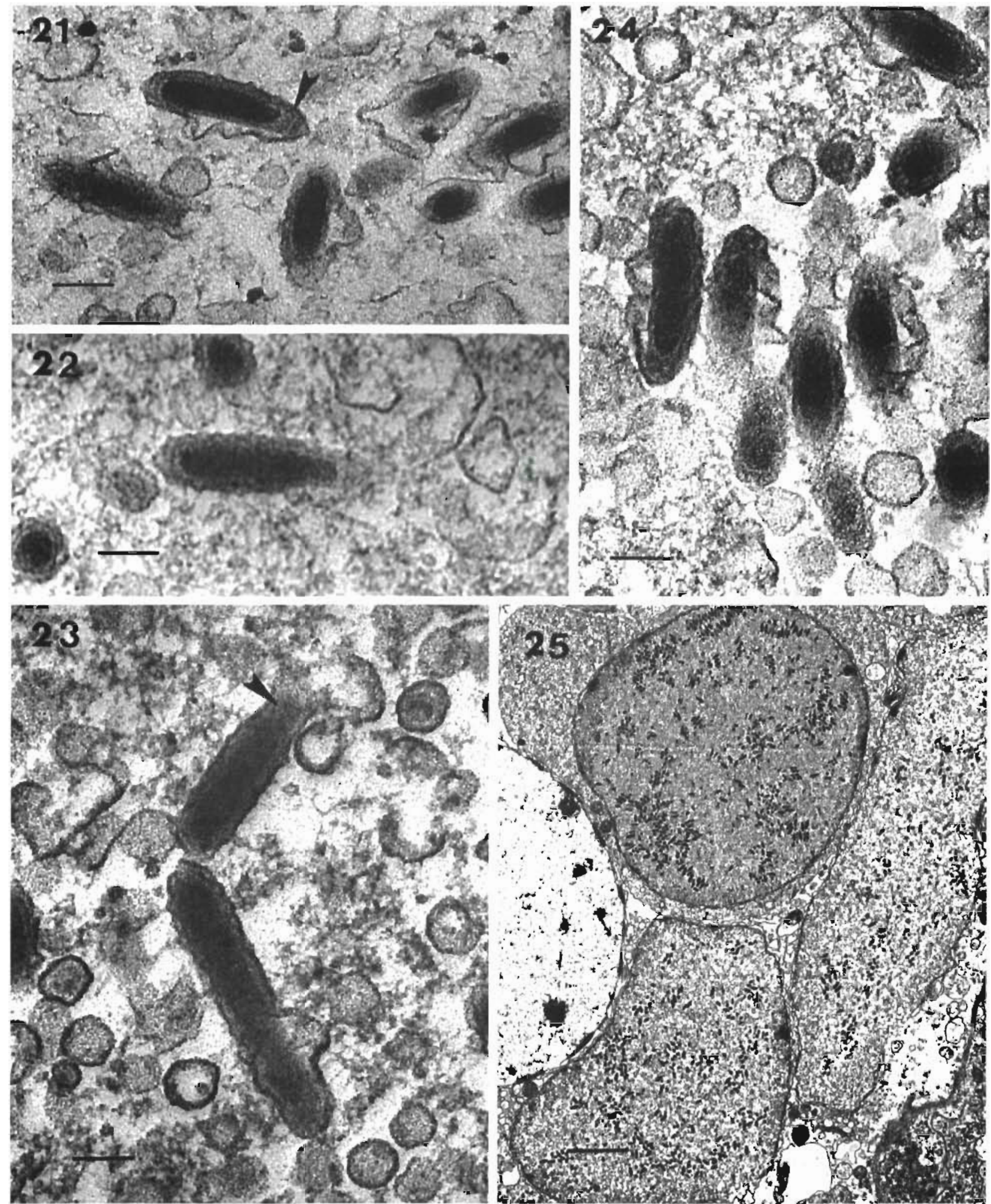

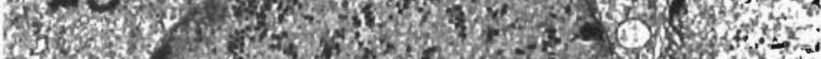

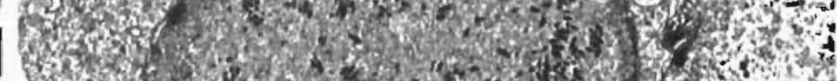

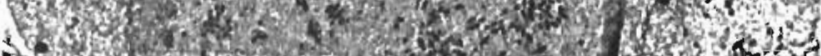

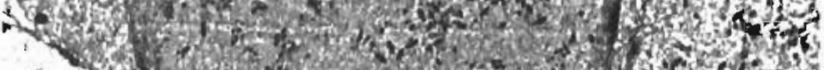

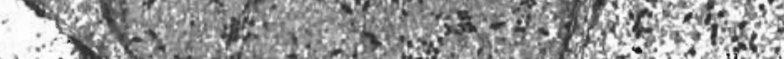

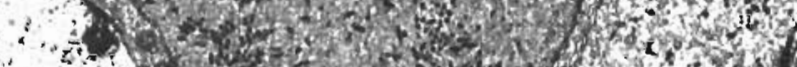

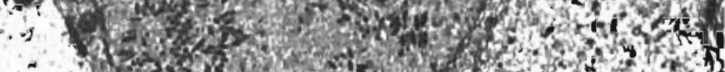

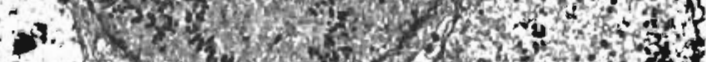

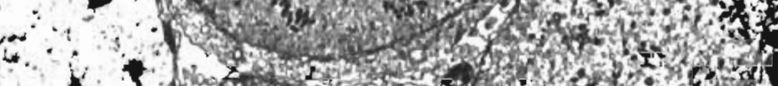

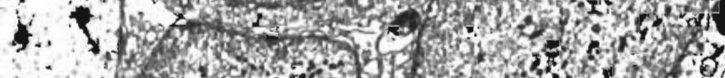

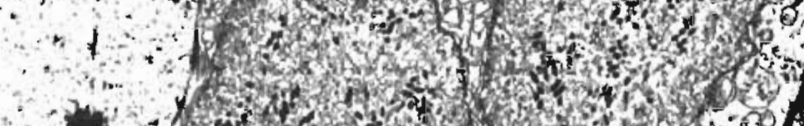
-

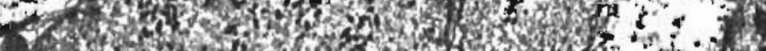

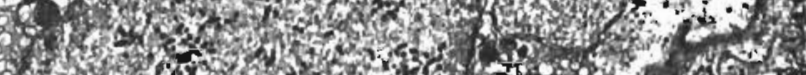

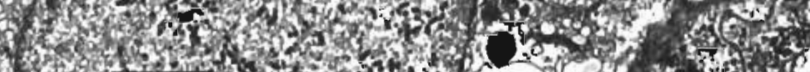

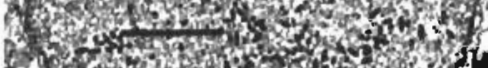

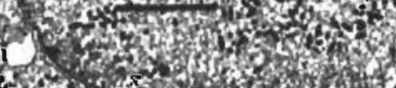

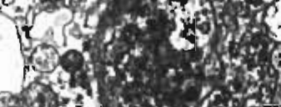

Figs. 21 to 25. Baculo-B. Fig. 21. Virion, showing thicker speclalızed end of the capsid (arrow) Bar $=106 \mathrm{~nm}$. Fig. 22 Core that appears like a baseball bat. One end is narrower and truncate Bar $=93 \mathrm{~nm}$ Flg 23 Nucleocapsid with open-ended envelope The capsid is squared and thickest at the specialized apex (arrow) An abnormally long virion, with closely fitting, wrinkled envelope lies below. Bar $=93 \mathrm{~nm}$. Fig. 24. Virions with complexly folded envelopes Bar $=93 \mathrm{~nm}$. Fig. 25 Three ınfected nuclei The one in the middle of the top half of the figuse has a very dense virogenic stioma and ordered arrays of vinons An uninfected nucleus in a lysing cell is to the left Bar $=137 \mu \mathrm{m}$ 
stromata (Fig 25) probably represented the most intensely Feulgen-positive nuclei observed with the light microscope.

The cytoplasm of infected cells contained free ribosomes, various vesicles and cisternae, mitochondria and, rarely, a Golgi complex. Except for the presence of appropriate virogenic stromata and viral particles, composition of the cytoplasm did not visibly differ between hemocytes infected only with Baculo-B and ones additionally infected with one or more of the following cytoplasmic viruses: Reolike Virus (RLV), Rhabdolike Virus A (RhVA), and Enveloped Helical Virus (EHV) (which is also a rhabdolike virus) (Johnson 1983, 1984).

Virions were released by cell lysis, were common in the hemolymph, and recognizable but presumably degraded Baculo- $B$ virions occurred in the secondary lysosome of a phagocytic hemocyte (Fig. 26). The envelopes of the phagocytized virions were spherical

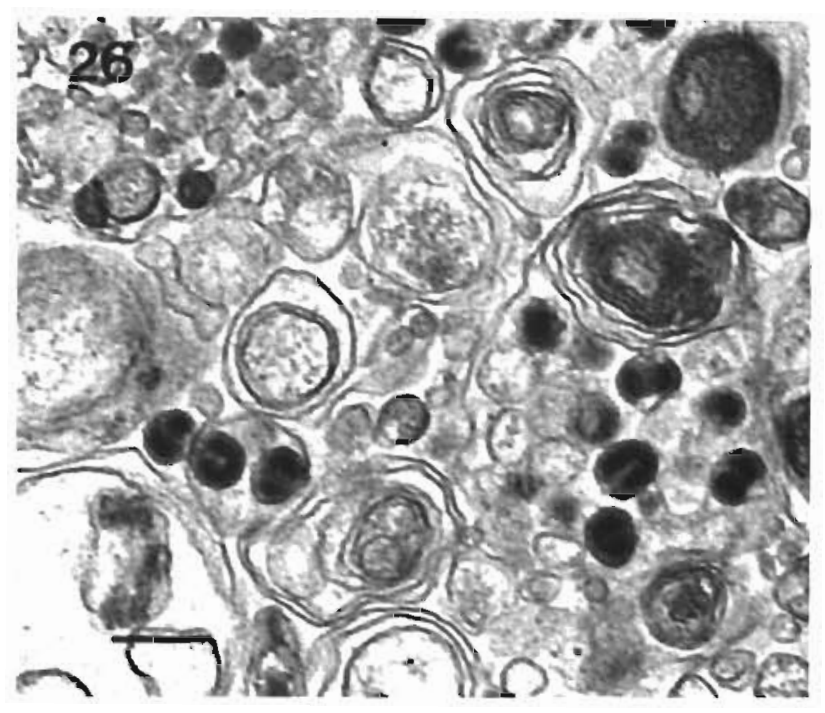

Fig. 26. Baculo-B. U-shaped, presumably necrotic nucleocapsids in spherical envelopes within a secondary lysosome in a hemocyte. $B a r=271 \mathrm{~nm}$

and, like normal RV-CM nucleocapsids, they apparently were forced to assume a U-shape in order to fit within the shortened envelope. However, the capsid of phagocytized Baculo-B virions was not distinguishable from the core, and dense material filled the area between the envelope and the nucleocapsid.

\section{DISCUSSION}

Baculo-B virions occur, although rarely, in the cytoplasm of intact cells whose nuclear and cytoplasmic domains have become mixed. 'Nuclear pores' traverse cisternae between mainly cytoplasmic parts in BaculoB cytoplasmic infection, and Pinnock \& Hess (1977) reported annulate lamellae to occur in cells infected with a granulosis virus (Subgroup B, Baculoviridae). Thus, both viruses apparently interacted with the host cell in a similar manner during reduction of differentiation of the nucleus from the cytoplasm.

The hemocyte-infecting species share certain developmental and morphological attributes with the Polydnaviridae, various unclassified rod-shaped nuclear viruses, and certain members of the Baculoviridae (Table 1). However, these similarities do not occur in a consistent manner and do not suggest that the hemocyte-infecting viruses are particularly related to any one species or group of the above viruses, including the rod-shaped nuclear viruses that infect the crustacean gut (Johnson \& Lightner 1988).

In the hemocyte-infecting species, the capsid of a finished particle is thicker than in most baculoviruses, and is less electron dense than the core. Further, the nucleocapsid has a greater diameter than the empty capsid. These characteristics are shared with an occluded virus from the mosquito Aedes triseriatus, which is otherwise like species of Subgroup A of the Baculoviridae (Federici 1980)

Before and usually after complete envelopment, thinsectioned nucleocapsids of Baculo-B and RV-CM are polarized because of the presence of the specialized apex, which may develop from the putative capsid originator. The mature, negatively stained nucleocapsids of some nuclear polyhedrosis viruses (NPVs) of Subgroup A of Baculoviridae are also polarized. An NPV from the lepidopteran Anthela varia has a 'nipple' engaged by a 'claw' on one end (Teakle 1969), and nucleocapsids of the NPV from Rachiplusia ou often have one end convex and the other flat or slightly concave, with inwardly curving papilla-like structures (Kawanishi \& Paschke 1970). It is assumed that similar polarity occurs in other baculoviruses (Summers 1977). Not all negatively stained nucleocapsids of $R$. ou appear to be polarized (Kawanishi \& Paschke 1970), and appearance of the 'end structures' differs according to whether uranyl acetate or phosphotungstic acid is used for negative staining (C. Y. Kawanishi pers. comm.). Whether polarity of the NPV nucleocapsid might involve a structure similar to the capsid originator of Baculo-B and RV-CM is unknown.

Determination of whether the genomes of the hemocyte-infecting crustacean viruses are double-stranded circular DNA will be a necessary first step before definite suggestions are made about their relationships to viruses currently placed in the Baculoviridae. They may be found to differ just as extensivel: from the Baculoviridae as, for example, the Polydnaviridae do. The latter viruses have a quasicylindrical nucleocapsid and several different species of double-stranded circuIar DNA (Stoltz et al. 1984, Brown 1986) 
Table 1. Attributes of crustacean hemocyte-infecting viruses and certain other rod-shaped viruses

\begin{tabular}{|c|c|c|c|c|c|c|c|c|c|}
\hline Viral species & Host & $\begin{array}{l}\text { Tissue } \\
\text { infected }\end{array}$ & $\begin{array}{l}\text { Occlusion } \\
\text { bodies }\end{array}$ & $\begin{array}{c}\text { Devel- } \\
\text { opment } \\
\text { with } \\
\text { mem- } \\
\text { branes }\end{array}$ & $\begin{array}{l}\text { Average } \\
\text { diameter } \\
\text { capsid/ } \\
\text { nucleo- } \\
\text { capsid }\end{array}$ & $\begin{array}{l}\text { Loose } \\
\text { envelope }\end{array}$ & $\begin{array}{l}\text { Vesicles } \\
\text { in } \\
\text { nucleus }\end{array}$ & $\begin{array}{l}\text { Nucleo- } \\
\text { capsid a } \\
\text { true } \\
\text { cylinder }\end{array}$ & Source \\
\hline $\mathrm{RV}-\mathrm{CM}$ & $\begin{array}{l}\text { Carcinus } \\
\text { maenas } \\
\text { (American) }\end{array}$ & $\begin{array}{l}\text { Hemocytes, } \\
\text { hemopoietic } \\
\text { tissue }\end{array}$ & $N_{O}$ & Yes & $67 / 100$ & Yes & Yes & No & This paper \\
\hline Baculo-B & $\begin{array}{l}\text { Callinectes } \\
\text { sapidus }\end{array}$ & $\begin{array}{l}\text { Hemocytes. } \\
\text { hemopoietic } \\
\text { tissue }\end{array}$ & No & Yes & $57 / 80$ & Yes & Yes & No & $\begin{array}{l}\text { Johnson (1983, } \\
\text { 1984) }\end{array}$ \\
\hline $\begin{array}{l}\text { Baculovirus } \\
\text { unnamed }\end{array}$ & $\begin{array}{l}\text { Carcinus } \\
\text { maenas } \\
\text { (European) }\end{array}$ & $\begin{array}{l}\text { Hemocytes, } \\
\text { connective } \\
\text { tissue }\end{array}$ & No & Yes & $50 / 77$ & Yes & Yes & No & $\begin{array}{l}\text { Bazin et al. } \\
\text { (1974), Mari \& } \\
\text { Bonami (pers. } \\
\text { comm.) }\end{array}$ \\
\hline $\begin{array}{l}\text { Polydna- } \\
\text { viridae }\end{array}$ & $\begin{array}{l}\text { Parasitic } \\
\text { ichneumonid } \\
\text { wasps }\end{array}$ & $\begin{array}{l}\text { Calyx of } \\
\text { ovary }\end{array}$ & No & Yes & $? / 40^{b}$ & Yes & No & No & $\begin{array}{l}\text { Stoltz \& Vinson } \\
(1979)\end{array}$ \\
\hline $\begin{array}{l}\text { Oryctes } \\
\text { virus }\end{array}$ & $\begin{array}{l}\text { Oryctes } \\
\text { rhinoceros } \\
\text { (beetle) }\end{array}$ & $\begin{array}{l}\text { Midgut, fat } \\
\text { body, etc. }\end{array}$ & No & Yes/Noc & $45 / 45$ & Yes & Yes & Yes & Huger (1966) \\
\hline $\begin{array}{l}\text { Gyrinus } \\
\text { virus }\end{array}$ & $\begin{array}{l}\text { Gyrinus } \\
\text { natator (beetle) }\end{array}$ & Midgut & No & Yes & $? / 35$ & Yes & No & No & $\begin{array}{l}\text { Gouranton } \\
\text { (1972) }\end{array}$ \\
\hline $\begin{array}{l}\text { Chaoborus } \\
\text { virus }\end{array}$ & $\begin{array}{l}\text { Chaoborus } \\
\text { crystallinus } \\
\text { (midge) }\end{array}$ & Midgut & No & Yes & $? / 40$ & No & No & Yes & $\begin{array}{l}\text { Larsson (1984, } \\
\text { pers. comm.) }\end{array}$ \\
\hline $\begin{array}{l}\text { Bacillus } \\
\text { virus }\end{array}$ & $\begin{array}{l}\text { Bacillus rossius } \\
\text { (stick insect) }\end{array}$ & Midgut & No & $?$ & $? / 55$ & Yes & Yes & Yes & $\begin{array}{l}\text { Scali et al. } \\
(1980)\end{array}$ \\
\hline $\begin{array}{l}\text { Diabrotica } \\
\text { virus }\end{array}$ & $\begin{array}{l}\text { Diabrotica un- } \\
\text { decimpunctata } \\
\text { (beetle) }\end{array}$ & Hemocytes & No & $?$ & $52 / 52$ & No & Yes & Yes & $\begin{array}{l}\text { Kim \& Kitajima } \\
(1984)\end{array}$ \\
\hline $\begin{array}{l}\text { BP } \\
\text { (Baculovirus } \\
\text { penaei) }\end{array}$ & $\begin{array}{l}\text { Penaeus spp. } \\
\text { (shrimp) } \\
\text { (American) }\end{array}$ & $\begin{array}{l}\text { Hepatopan- } \\
\text { creas, an- } \\
\text { terior midgut }\end{array}$ & Yes & Yes & $50 / 50$ & Yes & No & Yes & $\begin{array}{l}\text { Couch (1974), } \\
\text { Lightner et al. } \\
(1983)\end{array}$ \\
\hline Aedes virus & $\begin{array}{l}\text { Aedes } \\
\text { triseriatus } \\
\text { (mosquito) }\end{array}$ & Midgut & Yes & No & $35 / 48$ & No & No & Yes & $\begin{array}{l}\text { Frederici } \\
(1980)\end{array}$ \\
\hline \multicolumn{10}{|c|}{$\begin{array}{l}\text { a Measurements in } \mathrm{nm} \text { and based on thin sections } \\
\mathrm{b} ?=\text { unknown, unsure; or not stated in the paper and not demonstrated in the included figures } \\
\text { " Development known to take place with and without membrane }\end{array}$} \\
\hline
\end{tabular}

Acknowledgements. Thanks are due J. Swann of the Oxford Laboratory, who typed the manuscript and provided editorlal assistance, and R. R. Granados, Boyce Thompson Institute, Cornell University, Ithaca, New York, and D. V. Lightner, Environmental Research Laboratory, University of Arizona, who reviewed an earlier version of the manuscript.

\section{LITERATURE CITED}

Alberts, B., Bray, D., Lewis, J., Raff, M., Roberts, K., Watson, J. D. (1983). Molecular biology of the cell. Garland Publ. Inc., New York

Bazin, F., Monsarrat, P., Bonami, J. R., Croizier, G., Meynadier, G., Quiot, J. M., Vago, C. (1974). Particules virales de type baculovirus observées chez le crabe Carcinus maenas. Rev. Trav. Inst. Pêches marit. 38: 205-208

Brown, F. (1986). The classification and nomenclature of viruses: summary of results of meetings of the International Committee on Taxonomy of Viruses in Sendai, September 1984. Intervirology 25: 141-143

Couch, J. A. (1974). An enzootic nuclear polyhedrosis virus of pink shrimp: ultrastructure, prevalence, and enhancement. J. Invertebr. Pathol. 24: 311-331

Farley, C. A. (1969). Probable neoplastic disease of the hematopoietic system in oysters, Crassostrea virginica and Crassostrea gigas. Natl. Cancer Inst. Monogr. No. 31 : $541-555$

Federici, B. A. (1980). Mosquito baculovirus: sequence of morphogenesis and ultrastructure of the virion. Virology 100 : $1-9$

Gouranton, J. (1972). Development of an intranuclear nonoc- 
cluded rod-shaped virus in some midgut cells of an adult insect, Gyrinus natator L. (Coleoptera). J. Ultrastruct. Res, 39: $281-294$

Huger, A. M. (1966). A virus disease of the Indian rhinoceros beetle, Oryctes rhinoceros (Linnaeus), caused by a new type of insect virus, Rhabdionvirus oryctes gen. $\mathrm{n}$., sp. n. J. Invertebr. Pathol. 8: 38-51

Johnson, P. T (1980). Histology of the blue crab, Callinectes sapidus. A model for the Decapoda. Praeger, New York

Johnson, P. T. (1983). Diseases caused by viruses, rickettsiae, bacteria, and fungi. In: Provenzano, A. J. (ed) The biology of Crustacea, Vol. 6. Academic Press, New York, p. $1-78$

Johnson, P. T. (1984). Viral diseases of marine invertebrates. Helgoländer Meeresunters. 37: 65-98

Johnson, P. T., Lightner, D. V. (1988). Rod-shaped nuclear viruses of crustaceans: gut infecting species. Dis. rquat. Orq. 5: 123-141

Kawanishi, C. Y., Paschke, J. D. (1970). The relationsnip of buffer pH and ionic strength on the yield of virions and nucleocapsids obtained by the dissolution of Rachiplusia ou nuclear polyhedra. Proc. IVth Int. Collog. Insect Pathol., p. $127-146$

Kim, K. S., Kitajima, E. W. (1984). Nonoccluded baculovirusand filamentous virus-like particles in the spotted cucumber beetle, Diabrotica undecimpunctata (Coleoptera: chrysomelid). J. Invertebr. Pathol. 43: 234-241

Larsson, R. (1984). Baculovirus-like particles in the midgut epithelium of the phantom midge, Chaoborus crystallinus (Diptera, Chaoboridae). J. Invertebr. Pathol. 44: 178-186

Lightmer, D. V., Redman, R. M., Bell, T. A. (1983). Observations on the geographic distribution. pathogenesis and morphology of the baculovirus from Penaeus monodon Fabricius. Aquaculture 32: 209-233

Pinnock, D. E., Hess, R. T. (1977). Electron microscope observations on granulosis virus replication in the fruit tree leaf roller, Archips argyrospila: infection of the midgut. J. Invertebr. Pathol, 30: 354-361

Scali, V., Montanelli, E., Lanfranchi, A., Bedini, C. (1980) Nuclear alterations in a baculorirus-like infection of midgut epithelial cells in the stick insect, Bacillus rossius. J. Invertebr. Pathol. 35: 109-118

Spurr, A. R. (1969). A low viscosity epoxy resin emibedding me dium for electron microscopy. J. Ultrastruct. Res. 26: 31-43

Stoltz, D. B., Vinson, S. B. (1979). Viruses and parasitism in. insects. Adv. Virus Res. 24: 125-171

Siuliz, D. B., Krell, $r$., Summers, M. D., Vinson, S B (1984) Polydnaviridae - a proposed family of insect viruses with segmented, double-stranded, circular DNA genomes Intervirology $21: 1-4$

Summers, M. D. (1977). Baculoviruses. In: Maramorosch, K. (ed.) The atlas of insect and plant viruses. Academic Press, New York, p. 3-27

Teakle, R. E. (1969). A nuclear-polyhedrosis virus of Anthela varia (Lepidoptera: Anthelidae). J. Invertebr. Pathol. 14 $18-27$

Responsible Subject Editor: Dr J. E. Stewart; accepted for printing on July 5, 1988 